norden

Access and rights to forest genetic resources in the Nordic region

Current situation and future perspectives 




\section{Access and rights to forest genetic resources in the Nordic region}

Current situation and future perspectives

Tor Myking, Morten Walløe Tvedt, Øyvind Meland Edvardsen, Henrik Hallingbäck, Ditte Christina Olrik, Gunnar Friis Proschowsky, Mari Rusanen, Sanna Black-Samuelsson and Tore Skrøppa

TemaNord 2012:520 


\section{Access and rights to forest genetic resources in the Nordic region}

Current situation and future perspectives

Tor Myking, Morten Walløe Tvedt, Øyvind Meland Edvardsen, Henrik Hallingbäck, Ditte Christina

Olrik, Gunnar Friis Proschowsky, Mari Rusanen, Sanna Black-Samuelsson and Tore Skrøppa

TemaNord 2012:520

ISBN 978-92-893-2347-5

http://dx.doi.org/10.6027/TN2012-520

(C) Nordic Council of Ministers, Copenhagen 2011

Print: Kailow Express ApS

Oplag: 300

Cover photo: Ragnar Johnskås

Printed in Denmark

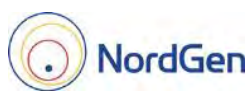

This publication has been published with financial support by the Nordic Council of Ministers. But the contents of this publication do not necessarily reflect the views, policies or recommendations of the Nordic Council of Ministers.

\section{www.norden.org/en/publication}

\section{Nordic co-operation}

Nordic co-operation is one of the world's most extensive forms of regional collaboration, involving Denmark, Finland, Iceland, Norway, Sweden, and the Faroe Islands, Greenland, and Åland.

Nordic co-operation has firm traditions in politics, the economy, and culture. It plays an important role in European and international collaboration, and aims at creating a strong Nordic community in a strong Europe.

Nordic co-operation seeks to safeguard Nordic and regional interests and principles in the global community. Common Nordic values help the region solidify its position as one of the world's most innovative and competitive.

\section{Nordic Council of Ministers}

Ved Stranden 18

DK-1061 Copenhagen $\mathrm{K}$

Phone (+45) 33960200 


\section{Content}

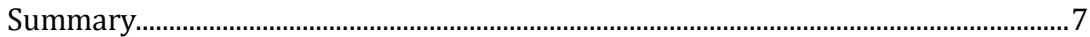

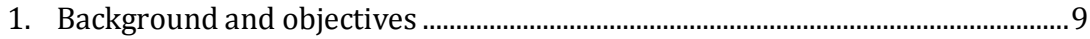

2. What is special about forest trees? .........................................................................11

3. International regulations and FGR ....................................................................... 13

3.1 The Convention on Biological Diversity ...................................................13

3.2 Genetic resource - the legal concept ………………………….................... 14

$3.3 \quad$ Intellectual property rights......................................................................... 14

3.4 Contracts.................................................................................................... 16

4. Today's situation in the Nordic region .............................................................. 17

4.1 The rights to genetic resources............................................................ 17

4.2 Some forest tree examples of commercial value ...................................... 18

5. What about the future? ……………………………………………………………... 21

5.1 ABS and the Nagoya Protocol..................................................................21

5.2 FAO Report: The State of the World's Forest Genetic Resources ........... 22

5.3 FOREST EUROPE - towards a legally binding agreement on forests in Europe............................................................................................ 23

6. Conclusions and recommendations ........................................................................2

6.1 Conclusions................................................................................................. 25

6.2 Recommendations under the aim of securing continuing flexible

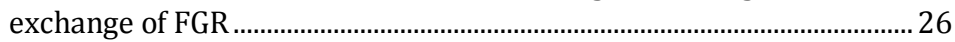

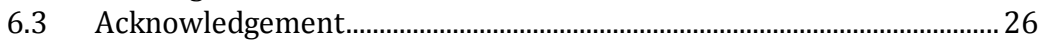

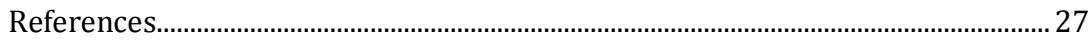

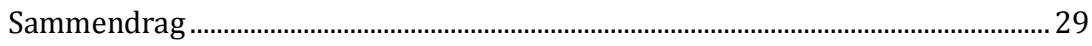





\section{Summary}

Continued flexible exchange of forest genetic resources (FGR) in the Nordic region is important for sustainable forest management and for climate change adaptation and mitigation. For this reason, a high level political initiative identified a need to clarify the legal status of FGR in the Nordic region. The overall aim of this study was to assess whether it is necessary and possible to take legal steps to ensure that FGR remain available for conservation and sustainable use in and between the Nordic countries. A survey of the present situation revealed that although the Nordic countries have different domestic legislation on access to FGR, it has not caused any hinders for exchange. Thus, in effect the situation is quite similar in the Nordic countries. As for the future, it is unlikely that application of patent law and plant variety protection (UPOV) will restrict exchange of FGR, mainly due to the short protection periods of these regulations relative to the long generation time of main forestry tree species. For short rotation tree species, intellectual property rights (IPR) might prove to be more applicable. Concerning international agreements, it is premature to evaluate the effect of the Nagoya Protocol (2010) on access and benefit sharing for FGR, as well as recent FAO initiatives. Based on the current study, no legal steps or action seem necessary. To promote continuing simple exchange of FGR the Nordic countries are recommended to stay involved in those processes where relevant international agreements are debated and developed, facilitate simple procedures for exchange and establish a mechanism for surveillance of biotechnological methods that might increase the use of private property rights on FGR. 



\section{Background and objectives}

The Convention on Biological Diversity (CBD) was adopted in 1992 and it is the main international framework for conservation of biodiversity. The CBD strengthened the political recognition of genetic resources as an invariable component of biological diversity. It also established legally binding obligations on access to genetic resources, as well as to fair and equitable sharing of the benefits arising (ABS) from the utilisation of genetic resources.

Even if these objectives and obligations of the CBD have been in force since 1993, the implementation in national legislation has showed poor results in making funding available to conservation measures. Therefore, a supplementing agreement (Nagoya Protocol), including rules for the implementation of ABS, was finalised in 2010.

The simple and non-bureaucratic exchange of forest genetic resources (FGR) between the Nordic countries is regarded as very valuable for the forestry sector as it secures access to seeds and breeding material across borders. But as the status of FGR has not been legally defined in three of the four countries explored, there is a risk that future developments in legislation could interfere negatively with the present practice. On 25 June 2003, the Nordic Council of Ministers (Fisheries, Agriculture, Forestry and Food) adopted a Nordic Ministerial Declaration on access and rights to genetic resources (GR) in Kalmar, Sweden. The declaration was approved by the Nordic Ministers of the Environment in Oslo on 28 October 2003. The Kalmar Declaration states that the Nordic countries should initiate a project aimed at providing a basis for the Nordic countries' decision on the legal status of their FGR. In 2008, the Nordic Council of Ministers granted NordGen Forest a project to explore these issues (2009-2010) in close collaboration with The Fridtjof Nansen Institute (FNI), Norway. 
The overall aim of the project was to clarify whether it is necessary and possible to take legal steps to ensure that FGR remain available for conservation and sustainable use, either in the public domain or through an open exchange system. The objectives were to:

- Describe the present situation as regards to access and rights to FGR in the Nordic countries

- Identify possible developments that could affect the present nonbureaucratic system of access to FGR

- Identify and discuss relevant case studies in which patenting is needed for commercialisation, and how this could be combined with the general open exchange system

- Propose relevant and applicable steps in law or policy, and recommendations for decision-makers as regards future challenges and FGR 


\section{What is special about forest trees?}

Trees differ from crop plants in many respects. The rotation time of forest trees is very long in the Nordic region, 60 to 100 years for several commercial species. As a consequence of their size and great reproductive capacity, the gene flow is also extensive. European aspen (Populus tremula) is a good example: a single tree may produce up to 80 million seeds annually. Related to the pronounced gene flow, most forest tree species also exhibit high genetic diversity as compared to other organisms. Another special characteristic is that when forest trees are planted, the next generation may be naturally regenerated from the planted material - contrary to plant varieties in agriculture where new seed are mostly used every year. This might imply that it is valuable to keep a high diversity also in the planted forests as they may be naturally regenerated in the future.

The Nordic region has only a few tree species, such as Norway spruce, Scots pine, beech, oak and silver birch, with commercial importance. Although the degree of domestication is modest, the use of bred material plays an increasing role, and several other tree species have potential commercial value. Most breeding is publicly financed, but some work is co-financed by forestry companies and/or forest owners.

The aim of forest tree breeding is currently to improve volume growth and quality traits, and at the same time enhance climatic adaptation and maintain genetic variation over the breeding generations. This aim is very different from achieving stable and uniform varieties as in the breeding of crop plants. However, the objectives may change. International trends, such as using fast-growing and genetically uniform varieties in the tropics (e.g. Eucalyptus spp.), may become more relevant for the Nordic region in the future. Fast-growing trees in the Nordic climate (e.g. Salix and Populus species) have been suggested as a solution for increasing sequestration of $\mathrm{CO}_{2}$. Furthermore, for specific productions such as Christmas trees, devel- 
opment of novel regeneration methods (e.g. somatic embryogenesis) and breeding for genetically more uniform varieties are already in progress.

The long rotation time in traditional forestry makes investments in forest trees less attractive than in crop plant production where rotation time is 1-2 years - and in some cases only months - allowing for several harvests annually. In some parts of forestry, however, the rotation time is shorter; for example Christmas trees and biofuel crops (e.g. Salix spp.), which have a rotation period of 3 to 15 years. For species with shorter rotation periods, the economic value of the genetic material probably increases. International laws for access and rights to plant genetic resources have been developed primarily for agricultural crops, without considering the differences in biology, growing conditions and life histories between crop plants and forest trees. 


\section{International regulations and FGR}

\subsection{The Convention on Biological Diversity}

The CBD is the most significant international agreement pertaining to biological material, including FGR. The background for regulating the access to genetic resources as part of the CBD was to establish a mechanism for sharing benefits arising from the commercial and other use of genetic resources. The CBD recognizes that countries have the sovereign rights over their genetic resources. This implies the competence to regulate and set conditions for the use of genetic material from one country under the jurisdiction of another country. Access and benefit sharing (ABS) is mainly an international mechanism. The access to and utilisation of genetic material from one country in another country shall be regulated by a permit (prior informed consent) and a private law agreement (mutually agreed terms) which sets out the conditions for fair and equitable sharing of the benefits arising from such use.

"Access" is mostly understood as the act of collecting or receiving samples of genetic material, whereas "benefit sharing" is a later step, when the outcome from the use of genetic material is supposed to be shared. The access side of the ABS was developed further in the non-binding Bonn Guidelines.

Despite the long time since the CBD entered into force, no European country has implemented a fully working regulation of access to its genetic resources, nor have many countries taken measures to ensure benefit sharing (Article 15.7). The essence of access regulation is that the provider country (or country of origin), is in the position to regulate conditions for accessing its resources. A country may employ its sovereign rights by choosing not to impose any regulations - which have been the approach of the Nordic countries, with the exception of Norway, thus far. 


\subsection{Genetic resource - the legal concept}

"Genetic resources" as a legal concept is not straightforward. The CBD (Article 2) defines "genetic resources" as genetic material of actual or potential value. The genetic material could be any material of plant, animal, microbial or other origin containing functional units of heredity. Clearly, FGR is covered by the definition in the CBD, which captures both current and future applications of genes and genetic information. Likewise, "value" is a broad term, and includes "social, economic, cultural and spiritual in nature." Although the definition of genetic resources is wide, it is likely that forest reproductive material (FRM) like seeds, seedlings or rooted cuttings, rather than single genes, will remain the main genetic material of interest for future application and regulations in the forestry sector. Regarding property rights, it is legally possible to separate the ownership to the biological material and the genetic resources therein. ${ }^{1}$ This distinction is crucial to establish rights to the genetic material. If such a distinction is not made, the right to the genetic material easily ends up merely being an element in the property right to the biological material.

\subsection{Intellectual property rights}

\subsubsection{Patents}

A patent is a way to achieve an exclusive right to a time-limited commercial use of an invention. For the Nordic countries there are two ways to get patent protection: by applying via the national patent office, or by applying for a European Patent through the European Patent Organisation (EPO). A patent can be granted for up to 20 years.

To be granted a patent the applicant must demonstrate that the invention is 1) novel, 2) involves an inventive step and 3) has potential for industrial application. In addition, the described invention must not be legally

\footnotetext{
${ }^{1}$ For a comprehensive discussion, see Tvedt 2010 chapter 2.
} 
exempted from patentability. The interpretation of what is meant by the term "essentially biological processes" is up for reinterpretation and a legal dispute in the appellate system of the EPO. These changes in practice might become relevant for breeding activities also in the forest sector. Normally, patents are granted to inventions, not discoveries. Novel in the patent law is not synonymous with absolutely non-pre-existing: it is merely a question of whether the invention has been identically described previously.

The patent law distinguishes between two types of patents, process and product related patents. Thus, breeding as a process can be patented if the above requirements are met. However, essentially biological processes are exempted from patenting. Once a process based patent is granted the protection also encompasses the products of the process. This so-called "indirect product protection" covers all products obtained by the patented process.

\subsubsection{Plant variety protection}

The Convention of the Union for Protection of Plant Varieties (UPOV Convention) is a harmonised international system to grant exclusive rights to commercially new plant varieties. For obtaining UPOV protection the criteria for novelty, distinctness, uniformity, and stability must be met. The criteria have been developed to encourage breeding of new plant varieties. UPOV protection can be given for up to 25 years for trees. It is most relevant for plant species with a short rotation time and has limited application in forestry. However for short rotation species, such as Christmas trees and species used in biofuel production, UPOV protection could have commercial relevance as long as the criteria are met. 


\subsection{Contracts}

A global tendency in crop plants is an increased use of a Standard Material Transfer Agreement accompanied by an increased use of contracts to enforce and benefit from IPR. The right to genetic material through the biological material as well as intellectual property rights can be traded, sold or otherwise transferred to other legal persons. However, there has been limited experience with the use of contracts in this field, and since 1993 no single ABS contract has been taken to court in any country of the world. The number of successful ABS-contracts outside the court system is also reportedly low. 


\section{Today's situation in the Nordic region}

\subsection{The rights to genetic resources}

Ownership to genetic resources rests on two principles rights; access to the land where the biological material (e.g. forest trees) is located, and the legal rights to the genetic resources per se - whether it follows ownership to the biological material or not.

\subsubsection{Access to the land}

Access to the land is a prerequisite for access to the genetic resources. In Sweden, Finland and Norway, access to public and private land is ensured by the Every man's right ("allemannsretten"). In Norway the Every man's right is legally regulated, whereas in Finland and Sweden the right is maintained by constitutional practice. In all these countries, the Everyman's right holds a very strong position, closely connected to recreational activities. Denmark is an exception from this Nordic pattern. Access to private forests is restricted to paths and roads. In public forests, however, access is possible everywhere.

\subsubsection{Ownership of genetic resources}

The Nordic countries have different laws and practices as concerns access to and ownership of genetic resources. Norway is the only country which has established a legal distinction between the biological and the genetic material (Norwegian Nature Diversity Act, 2009). The genetic material is defined as a common property which is managed by the government, whereas the biological resource is owned by the landowner, or any legal person who has formally gained the rights. Common for the other coun- 
tries, however, is that ownership to the biological material is decisive for ownership to the genetic resources. The rights to the biological material are dealt with in a variety of different laws in the different countries. Although small scale private collection of biological material (e.g. berries, cones on the ground etc) is free in all countries when access to the land is granted, commercial collection of cones and seeds requires permission from the landowners in the case of Finland, Sweden and Denmark. Although cone collection takes place on the ground after logging and is subject to Every man's right, Norway has also ensured that this takes place after agreement with the forest owners. Thus, irrespective of national legislation there are no practical differences among the countries as regards ownership to FGR.

\subsection{Some forest tree examples of commercial value}

\subsubsection{Finland: The red-leaved birch}

The red-leaved birch (Betula pubescens, f. rubra) was found in the 1970s by a school child. In spring the emerging leaves are green with a reddish tinge at the edges, but after 2 to 3 weeks the leaves turn dark red. The red leaved birch has high aesthetic value, but no seed production. Multiplication of the red-leaved birch failed initially, but in 1988 a successful propagation protocol was developed and tens of thousands of plants have been produced thereafter.

The red leaved birch is taxonomically described as a forma. If it had been described as plant variety, it could have been eligible for plant breeder's rights (UPOV protection), provided that it had not been offered for commercial sale before the application for the exclusive right. The distinction between forma and plant variety is perhaps of less importance for UPOV protection. The critical step would rather be if the red-leaved birch fulfilled the particular UPOV criteria for plant varieties (novelty, distinctness, uniformity, stability).

The red-leaved birch could also have been eligible for patent protection if it was described at the gene or cell level. 
The red-leaved birch, a mutant which has become commercially important

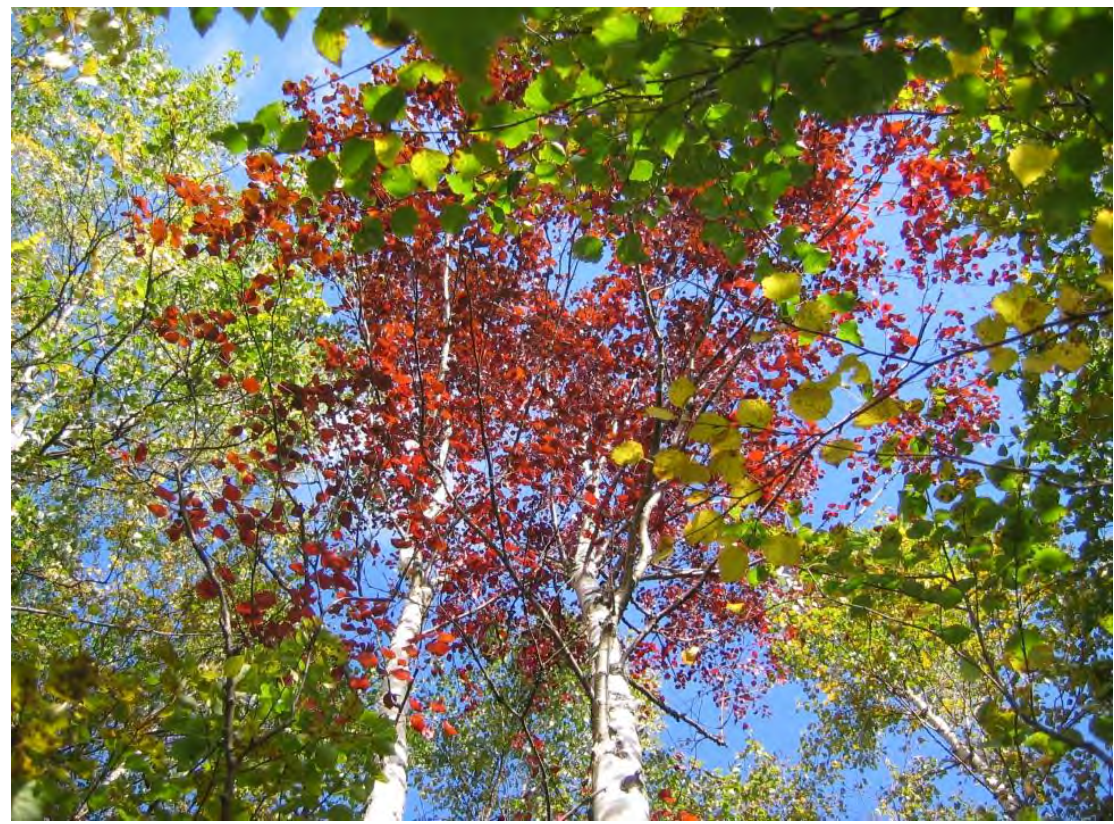

Photo: Mirja Siuruainen

\subsubsection{Denmark: Using contract law}

In a specific case a private company has signed a material transfer agreement with the Nature Agency, giving the private company access to controlled crossings of selected plus trees for the purposes of research and production. The intention is to establish a right for the private company to use the genetic resources, but still keep the ownership to the genetic resources in the public breeding programme.

\subsubsection{Norway: Ornamental forms of conifers}

Certain juniper clones have gained a trademark protection (e.g. "Oskeladden"). For trademarks the protection is different from that of patents by the fact that the commercial right targets the name as such, and not the genetic resource or plant variety. 


\subsubsection{Sweden: Patent protection of biotechnological methods}

The Swedish company SweeTree claims patent protection for various biotechnological methods for regulating expression of genes that have been functionally characterised. Some of the claims include protection of breeding activities that use the detection of proteins or metabolites expressed by the patented genes as a selection trait. Patent applications with particular interest for this work include characterisation of poplar genes involved in early flowering, the role of amino acid transporters in plant growth and suppression of polypeptide expression to increase growth.

Conclusion: Several of the examples have an unutilised potential for receiving some kind of legal protection, and all applications for patent protection (Sweden) are quite recent. Possibly, it has been a lack of awareness of the potential in achieving legal protection using patents and UPOV, and the case of the red-leaved birch was premature as Finland did not join UPOV until 1991. Thus, there are possibilities for increased use of patent and UPOV protection in the future, but likely limited to species and varieties which have less importance for forestry as such, and in most European countries recognised as agricultural crops (e.g. Christmas trees, biofuels crops). 


\section{What about the future?}

\subsection{ABS and the Nagoya Protocol}

The Nagoya Protocol (2010) is an international agreement to implement the legally binding regulation of access and benefit sharing of the CBD. Thus, the Nagoya Protocol is a supplement to the Bonn guidelines (2002) which are not legally binding. Even though FGR has not been a central topic in the debates, there are no particular rules that would exempt forest tree genetic resources from the scope of the Nagoya Protocol. The Protocol was initially intended to dealing mainly with legislation in user countries, but it covers both rules on access and on benefit sharing.

It is too early to evaluate how the Protocol will influence the ABS regime and the exchange pattern between the Nordic countries. A strategic point is whether the forest tree sector should identify regulations under the Protocol which could be conducive for a functional ABS system for FGR. The future will possibly require enhanced need for exchanging FGR across borders for mitigating climate change. Not all of the material is bred, but globally a great part is collected from natural stands. It is imperative that this is not hampered by regulations developed for other species than forest trees under the CBD, which eventually could have counterproductive effects for the forest sector. 


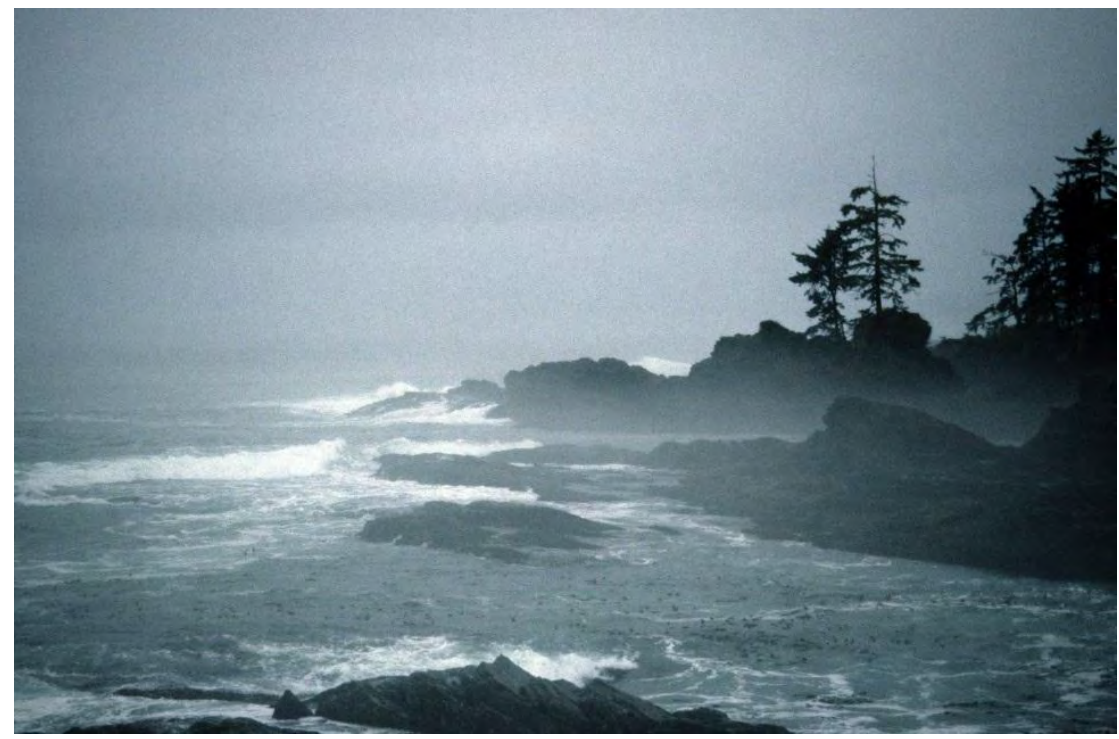

Photo: Arne Steffenrem

\subsection{FAO Report: The State of the World's Forest Genetic Resources}

The $12^{\text {th }}$ Regular Session of the FAO Commission of Genetic Resources for Food and Agriculture decided that a report on the state of the world's genetic resources should be prepared and presented in 2013. An Intergovernmental Technical Working Group on FGR was appointed to oversee the preparation of the report. Each Country Report must contain a chapter describing the state of access to forest genetic resources, transfer and sharing benefits arising from their use. National legislation, regulations, policies and other actions should also be presented. This global report will give a view of the overall situation as regards ABS on FGR and be a basis for further follow-up initiatives on these topics. The Commission on Genetic Resources for Food and Agriculture (CGRFA) under FAO has decided to address ABS at an intersession meeting before their next regular meeting in 2013. 


\subsection{FOREST EUROPE - towards a legally binding agreement on forests in Europe}

FOREST EUROPE (formerly the Ministerial Conference on the Protection of Forests in Europe, MCPFE), is a high-level political initiative working towards the protection and sustainable management of European forests. The first Ministerial Conference took place in Strasbourg in 1990. The preamble for the sixth conference, held in Oslo in 2011, included a decision to undertake negotiations on a Legally Binding Agreement (LBA) on forests in Europe with emphasis on inter alia sustainable forest management and climate change mitigation. This LBA is in its infancy, but it is quite clear that it will be based on existing international agreements, not the least the CBD and UN Framework Convention on Biological Diversity. It is expected to be finalised by 2013 . 



\section{Conclusions and recommendations}

\subsection{Conclusions}

- The Nordic countries have different domestic legislation for regulation of access to genetic resources (e.g. the Every man's right), but to the present day these differences have not caused any hinders for exchange and access to FGR

- The Nagoya Protocol on access and benefit sharing applies to FGR, but it is too early to conclude its implications for the forestry sector.

- A legally binding agreement on forests in Europe is under preparation, specifically targeting inter-alia sustainable forest management and climate change mitigation. This will have to adhere to existing international agreements, i.e. the CBD and UN Framework Convention on Biological Diversity

- It is unlikely that the patent law poses a threat for access to FGR because of the short patent protection period of 20 years. For short rotation species, however, such as Christmas trees (10 to 15 years) and biofuel crops (3 to 5 years) the situation could be different

- UPOV protection could be relevant for short rotation tree species as long as they fulfil the specific criteria for protection. For forest trees, it is unlikely to be applicable as the criteria will not be met, and due to the protection period of 25 years

- All in all, given the practice in the Nordic countries, and the forthcoming and present international legislative regime, developments that could hinder access and exchange of FGR in the Nordic region could not be identified. Therefore, no specific legal steps seem necessary 


\subsection{Recommendations under the aim of securing continuing flexible exchange of FGR}

- Stay involved: The National authorities should secure active participation in the processes where relevant international agreements are formed (COP, FAO, FOREST EUROPE). This applies particularly to the legally binding agreement of FOREST EUROPE which is under preparation

- Simple procedures: Increased international regulations on genetic resources, although intended for securing exchange among countries, might increase the bureaucratic burden and in turn counteract effective exchange. Thus, smooth bureaucratic procedures for exchange should be developed/maintained

- Surveillance: Biotechnological methods become increasingly used and could have consequences for the forest sector and application of private property rights unforeseen today. This advocates monitoring the situation as concerns regulation of access to FGR as well as monitoring patent applications relevant for the forest sector

- Publish: Encourage the publishing of descriptions of processes or inventions that are previously known to contribute to the prior art and thus not fulfil the criteria for being patented

\subsection{Acknowledgement}

We wish to thank Jarkko Koskela for valuable comments on this report. This project was financed by the Nordic Council of Ministers (grant no 092), money in kind from the individual participating countries and NordGen Forest. 


\section{References}

This report is based on Tvedt, M.W. (2011). Seeking appropriate legislation regulating access and exclusive rights to forest genetic resources in the Nordic region. FNI Report 9/2011. 



\section{Sammendrag}

Fortsatt fleksibel utveksling av skogtrærs genetiske ressurser (SGR) i Norden er viktig for bærekraftig skogbruk og tilpasning til klimaendringer. Av den grunn har det blitt besluttet på høyt politisk nivå at den rettslige statusen for SGR burde avklares. Hovedmålet med denne studien er å vurdere om det er nødvendig og mulig å ta rettslige skritt for å sikre at SGR forblir tilgjengelig for bevaring og bruk innen og mellom de nordiske land. En kartlegging av dagens situasjon viste at de nordiske land har forskjellig lovgivning for tilgang og rettigheter til SGR, men at dette ikke har vært til hinder for utveksling over landegrensene. Effekten av forskjellig lovning har altså ikke hatt nevneverdig praktisk betydning. For fremtiden er det lite sannsynlig at patentering og lovgivning for beskyttelse av plantevarianter (UPOV) vil hindre utveksling av SGR, hovedsakelig på grunn av den korte beskyttelsestiden disse lovene kan gi i forhold til trærnes generasjonstid. For kommersielle arter med kort generasjonstid (for eksempel juletrær og Salix-arter) er situasjonen en annen, og patentering og UPOVbeskyttelse kan være mer aktuelt. I forhold til internasjonale avtaler der det for tidlig å evaluere hvilken betydning Nagoya-protokollen (2010), som regulerer tilgang til genressurser og fordeling av utbytte ved bruk (access and benefit sharing, ABS), vil ha for SGR. Dette gjelder også nylige FAO-initiativ. Basert på denne studien synes det ikke å være nødvendig å foreta rettslige skritt for å sikre tilgang til SGR. For å fremme fortsatt fri utveksling av SGR anbefales det at de nordiske land er involvert i de prosessene hvor relevante internasjonale avtaler utvikles og forhandles frem, at de fremmer enkle prosedyrer for utveksling av SGR mellom landene og etablerer et system for å overvåke bioteknologiske metoder som kan øke privatiseringen av eiendomsretten til SGR. 
Nordic Council of Ministers

Ved Stranden 18

DK-1061 Copenhagen K

www.norden.org

\section{Access and rights to forest genetic resources in the Nordic region}

Continued flexible exchange of forest genetic resources (FGR) in the Nordic region is important for sustainable forest management and for climate change adaptation and mitigation. For this reason, a high level political initiative identified a need to clarify the legal status of FGR in the Nordic region.

In this report we summarise the results of a Nordic project intended to approach this issue, on the background that plant genetic resources is being increasingly subjected to private property rights. The aim of this work is to give recommendations for politicians and decision makers. 